\title{
Fos-Related Antigen 2
}

National Cancer Institute

\section{Source}

National Cancer Institute. Fos-Related Antigen 2. NCI Thesaurus. Code C18531.

Fos-related antigen 2 (326 aa, $\sim 35 \mathrm{kDa}$ ) is encoded by the human FOSL2 gene. This protein plays a role in the regulation of gene transcription. 